\title{
FUS/ERG Fusion Protein
}

National Cancer Institute

\section{Source}

National Cancer Institute. FUS/ERG Fusion Protein. NCI Thesaurus. Code C99282.

A fusion protein encoded by the FUS/ERG fusion gene. This protein is comprised of at least half of the RNA-binding protein FUS fused to the C-terminal portion of the transcriptional regulator ERG protein, which includes the ETS DNA binding domain. 